Наталія Ткаченко, Мирослава Хуторна

\title{
НАУКОВІ ПІДХОДИ ДО ЗАБЕЗПЕЧЕННЯ ФІНАНСОВОЇ СТАБІЛЬНОСТІ БАНКІВ З ПОЗИЦЇ̈ СУЧАСНОЇ ТРАНСФОРМАЦЇ̈ ЕКОНОМІЧНОГО СЕРЕДОВИЩА
}

\section{Наталия Ткаченко, Мирослава Хуторна \\ НАУЧНЫЕ ПОДХОДЫ К ОБЕСПЕЧЕНИЮ ФИНАНСОВОЙ СТАБИЛЬНОСТИ БАНКОВ С ПОЗИЦИИ СОВРЕМЕННОЙ ТРАНСФОРМАЦИИ ЭКОНОМИЧЕСКОЙ СРЕДЫ}

Nataliia Tkachenko, Myroslava Khutorna

\section{SCIENTIFIC APPROACHES TO ENSURING THE FINANCIAL STABILITY OF BANKS IN CURRENT TRANSFORMATION OF THE ECONOMIC ENVIRONMENT}

Досліджено особливості прямого та зворотного підходу до дослідження фінансової стабільності. Виявлено межі континуумів станів фінансової стабільності, фінансової крихкості та фінансової нестабільності. Представлено змістовність базових заходів із формування системи забезпечення фінансової стабільності банків. Наочно подано місие стратегічної «пастки» банків за умови одновекторності їхніх иільових орієнтирів. Акиентовано увагу на напрямах управління банківською установою та забезпечення ї̈ фінансової стабільності - функиіональному, ситуаційному та прочесному. Систематизовано вимоги щодо управління банком у контексті забезпечення його фінансової стабільності та на цій підставі сформовано функиіональність системи управління фінансовою стабільністю окремого банку.

Ключові слова: фінансова стабільність; банк; фінансова нестабільність; режими фінансування; системний підхід; бізнес-модель функиіонування банку; ризики.

Рис.: 3. Табл.: 2. Бібл.: 10.

Исследованы особенности прямого и обратного подхода к изучению финансовой стабильности. Выявлено предель континуума состояний финансовой стабильности, финансовой хрупкости и финансовой нестабильности. Представлена содержательность базовых мероприятий по формированию системы обеспечения финансовой стабильности банков. Наглядно представлено место стратегической «ловушки» банков при одновекторности их иелевых ориентиров. Акиентировано внимание на направлениях управления банковским учреждением и обеспечения его финансовой стабильности - функииональном, ситуачионном и процессном. Систематизированы требования по управлению банком в контексте обеспечения его финансовой стабильности и на этом основании сформирована функциональность системы управления финансовой стабильностью отдельного банка.

Ключевые слова: финансовая стабильность; банк; финансовая нестабильность; режимы финансирования; системный подход; бизнес-модель функиионирования банка; риски.

Рис.: 3. Табл.: 2. Библ.: 10.

The peculiarities of direct and reverse approach to the study of financial stability are investigated. The boundaries of the continuum states of financial stability, financial fragility and financial instability are revealed. The content of basic measures for the formation of a system for ensuring the financial stability of banks is presented. The place of the strategic "trap" of banks is clearly presented, provided that their targets are one-vector. Emphasis is placed on the areas of management of a banking institution and ensuring its financial stability - functional, situational and procedural. The requirements for bank management in the context of ensuring its financial stability are systematized and on this basis the functionality of the financial stability management system of an individual bank is formed.

Key words: financial stability; bank; financial instability; financing regimes; system approach; business model of bank functioning; risks.

Fig.: 3. Table: 2. References: 10.

JEL Classification: G21; E63

Постановка проблеми. Банківська система будь-якої країни, що сформована як надійна, стійка, стабільна, конкурентоспроможна та незалежна, може повноцінно виконувати свої функції, а також розвиватися відповідно до національних інтересів держави. Важливою умовою динамічного розвитку економіки країни $є$ забезпечення фінансової стабільності банків. До того ж в умовах глобальних дисбалансів, інтегрованості фінансових систем різних країн і постійного впливу ризиків, досягнення фінансової стабільності банківських установ $є$ також одним із ключових завдань урядів і центральних банків. Світ невпинно змінюється, оскільки перебуває на межі четвертої промислової революції, яка, крім великого потенціалу, спричинить потужні ризики нестабільності, зокрема й фінансової. Тому актуальність проблеми фінансової стабільності не знижується, а навпаки посилюється, а наукове товариство активно досліджує цей феномен.

(C) Ткаченко Н. В., Хуторна М. Е., 2020 
ФІНАНСОВІ РЕСУРСИ: ПРОБЛЕМИ ФОРМУВАННЯ ТА ВИКОРИСТАННЯ

Аналіз досліджень і постановка завдання. Однією 3 перших фундаментальних праць, присвячених вивченню теорії фінансової стабільності, є праця Х. Мінскі [1], теоретичні положення якої були в подальшому поглиблені та оприлюднені в основній праці науковця [2]. Також вагомий науковий внесок у розвиток методології фінансової нестабільності зробили А. Crockett [3], R. Ferguson [4], A. Large [5], G. Schinasi [6]. Ceред вітчизняних науковців необхідно відзначити науковий доробок О. Барановського, Я. Белінської, В. Биховченка, В. Гейця, А. Кузнєцової, О. Луняков, В. Міщенка, Л. Примостки, Т. Смовженко, Т. Унковської та інших, які досліджують рушійні чинники зародження та розгортання світових фінансово-економічних криз, обгрунтовують механізм забезпечення фінансової стабільності економіки та макроекономічної стабільності загалом, працюють над розробкою науково-методичних підходів своєчасного прогнозування, попередження та пом'якшення кризових явищ.

Виділення недосліджених частин загальної проблеми. Останніми роками органи банківського нагляду посилили свої заходи, спрямовані на забезпечення фінансової стабільності банків. Сучасний етап розвитку банківництва, що характеризується активізацією ролі банківських установ у фінансовій економіці, зумовлює потребу у формуванні та продукуванні соціально орієнтованого, процесного, корпоративного менеджменту в управлінні банківською діяльністю. За таких умов важливості набуває формування моделі стабільного функціонування окремих банків, що актуалізує пошуки основних напрямів та інструментів подолання кризових явищ в їхній діяльності та сприяє забезпеченню стабільності банків.

Метою статті є обгрунтування методологічних основ забезпечення фінансової стабільності банків.

Виклад основного матеріалу. Взаємозв'язки та взаємозалежності між окремими банками, іншими фінансовими установами, суб'єктами реального сектору економіки, домогосподарствами та державою є досить складними і такими, що потребують постійної прискіпливої уваги. 3 огляду на зазначене, коли йдеться про формування фінансової стабільності банківських установ, варто акцентувати увагу на обгрунтованому виборі комплексу методологічного інструментарію з метою:

- по-перше, розбудови такої системи як на рівні окремих банків, так і їх сукупності, тобто мезорівні;

- по-друге, комплексного аналізування загроз фінансовій стабільності банків, ідентифікування взаємообумовленостей та взаємозв'язків між ними для вчасного впровадження превентивних заходів щодо формування негативних синергетичних ефектів 3 урахуванням прямих та зворотних зв'язків;

- по-третє, забезпечення прийняття ефективних рішень, які дозволять як створити підгрунтя для безперебійного функціонування банківських установ відповідно до їхніх фінансово-стратегічних пріоритетів, так і сприятимуть стабільному функціонуванню економічних агентів;

- по-четверте, підтримання фінансової стабільності банків незалежно від фази економічного циклу, тобто як в умовах економічного пожвавлення, піднесення і економічного буму, так і кризового та посткризового періодів.

Варто зазначити, що теоретична концептуалізація фінансової стабільності перебуває на початковому етапі свого розвитку і єдиного іiі концептуального базису досі ще не вироблено. При цьому в сучасній науковій літературі виділяють два теоретичних підходи щодо дослідження фінансової стабільності, а саме прямий та зворотний. Безперечно, говорити про універсальність того чи іншого підходу немає сенсу, оскільки абсолютно виправданим $є$ використання різних напрямів розвитку теоретичного підгрунтя 3 розглядуваної проблематики в контексті вирішення різних наукових завдань фінансової стабільності. У табл. 1 узагальнено відмінності прямого та зворотного підходів до дослідження фінансової стабільності. 
Таблиця 1

Узагальнення відмінностей у підходах до дослідження фінансової стабільності

\begin{tabular}{|c|c|c|}
\hline \multirow{2}{*}{$\begin{array}{c}\text { Напрями } \\
\text { дослідження }\end{array}$} & \multicolumn{2}{|c|}{ Теоретичні підходи до дослідження фінансової стабільності } \\
\hline & Прямий підхід & Зворотний підхід \\
\hline $\begin{array}{l}\text { Базове поняття, яке } \\
\text { досліджується. }\end{array}$ & Фінансова стабільність & Фінансова нестабільність \\
\hline $\begin{array}{l}\text { Теорії, що викорис- } \\
\text { товуються }\end{array}$ & $\begin{array}{l}\text { Теорія економічної рівноваги, теорія фінансо- } \\
\text { вої рівноваги; теорія життєвого циклу }\end{array}$ & $\begin{array}{l}\text { Теорія криз, теорія життєвого } \\
\text { циклу. }\end{array}$ \\
\hline $\begin{array}{l}\text { Сукупність понять, } \\
\text { на яких формується } \\
\text { науко-базовий ін- } \\
\text { струментарій }\end{array}$ & $\begin{array}{l}\text { «Розвиток», «зростання», «адаптаційний поте- } \\
\text { нціал», «безперебійність функціонування», } \\
\text { «превентивний характер дій суб’єктів» }\end{array}$ & $\begin{array}{l}\text { «Банкрутство», «криза», «загро- } \\
\text { за», «дисбаланси», «стійкість», } \\
\text { «поточне протистояння шокам». }\end{array}$ \\
\hline \multicolumn{3}{|c|}{ Особливості вирішення окремих наукових завдань, зокрема: } \\
\hline $\begin{array}{l}\text { Формування механі- } \\
\text { зму забезпечення } \\
\text { фінансової стабіль- } \\
\text { ності }\end{array}$ & $\begin{array}{l}\text { Орієнтація на методи та інструменти забезпе- } \\
\text { чення, що дозволяють упереджувати зниження } \\
\text { цільового рівня фінансової стабільності. Своє- } \\
\text { часна реакція на тенденції до накопичення } \\
\text { дисбалансів. }\end{array}$ & $\begin{array}{l}\text { Орієнтація на методи та інстру- } \\
\text { менти забезпечення, що дозво- } \\
\text { ляють упереджувати фінансову } \\
\text { нестабільність, тобто настання } \\
\text { кризового стану установи шля- } \\
\text { хом запобігання критичному } \\
\text { накопиченню дисбалансів та } \\
\text { зниженню їхнього негативного } \\
\text { впливу }\end{array}$ \\
\hline $\begin{array}{l}\text { Оцінка рівня фінан- } \\
\text { сової стабільності }\end{array}$ & $\begin{array}{l}\text { Передбачає встановлення двох еталонних зна- } \\
\text { чень (максимального та мінімального). Мак- } \\
\text { симальне значення відповідає стану абсолют- } \\
\text { ної фінансової стабільності; мінімальне - } \\
\text { стану фінансової нестабільності. Рівень фінан- } \\
\text { сової стабільності представляється як інтерва- } \\
\text { льне значення між двома критичними точками }\end{array}$ & $\begin{array}{l}\text { Передбачає оцінку ймовірності } \\
\text { дефолтного стану установ. Уста- } \\
\text { нови вважаються фінансово ста- } \\
\text { більними, якщо ймовірність їх } \\
\text { банкрутства близька до нуля }\end{array}$ \\
\hline \begin{tabular}{|l} 
Моніторинг і конт- \\
роль за рівнем фі- \\
нансової стабільнос- \\
ті \\
\end{tabular} & $\begin{array}{l}\text { Об’єктом уваги є відхилення від заплановано- } \\
\text { го тренду розвитку в межах континууму фі- } \\
\text { нансової стабільності }\end{array}$ & $\begin{array}{l}\text { Об’єктом уваги є дисбаланси, } \\
\text { накопичення яких провокує ви- } \\
\text { хід системи } 3 \text { континууму станів } \\
\text { фінансової стабільності }\end{array}$ \\
\hline
\end{tabular}

Джерело: складено авторами.

За нашими міркуваннями, на влучний та обгрунтований вибір конкретного підходу до дослідження фінансової стабільності банків, впливає стан зовнішнього середовища, в якому вони функціонують. Зважаючи на модель економічного циклу, що запропонована X. Мінскі у рамках «Гіпотези фінансової нестабільності», зазначається, що використання прямого підходу є виправданим у випадку домінування в економіці забезпеченого фінансування, що, зазвичай, має місце, коли цикл ділової активності економічних агентів перебуває у фазі пожвавлення. Така гіпотеза пояснюється тим, що банківські установи саме у фазі пожвавлення ділової активності виявляють підвищену обережність під час укладання фінансових угод та мають схильність до переоцінки ризиків, зокрема фінансових.

Окрім того, під впливом активізації інвестицій спостерігається зростання національного доходу. Це призводить до зменшення ризиків як кредиторів, так і позичальників та зумовлює поступовий перехід економічних агентів до режиму спекулятивного та понціфінансування. Такий стан речей трансформує ставлення економічних агентів до ризику, а також суттєво знижує адекватність його оцінки. За таких умов кредитні установи входять у континуум станів фінансової крихкості, який, на нашу думку, також можна тлумачити як континуум біфуркаційних станів.

Зазначимо, що за умови своєчасних, дієвих та ефективних заходів тих чи інших суб' єктів забезпечення фінансової стабільності банків відбувається їх повернення до континууму станів фінансової стабільності. При цьому важливо відновити/зберегти здат- 
ФІНАНСОВІ РЕСУРСИ: ПРОБЛЕМИ ФОРМУВАННЯ ТА ВИКОРИСТАННЯ

ність кредитних установ до продукування кредитних ресурсів, оскільки це сприяє створенню позитивних зворотних зв'язків, оскільки стабільне функціонування економічних агентів стимулює позитивні кількісно-якісні зміни в діяльності кредитних установ.

Залежно від типу режиму фінансування, які трактуємо за Х. Мінскі, перехід банківських установ від стану фінансової стабільності до фінансової нестабільності можна представити за допомогою дескриптивної моделі циклічного їх розвитку. Така модель дозволяє означити межі континуумів станів їхньої фінансової стабільності, фінансової крихкості та фінансової нестабільності (рис. 1).

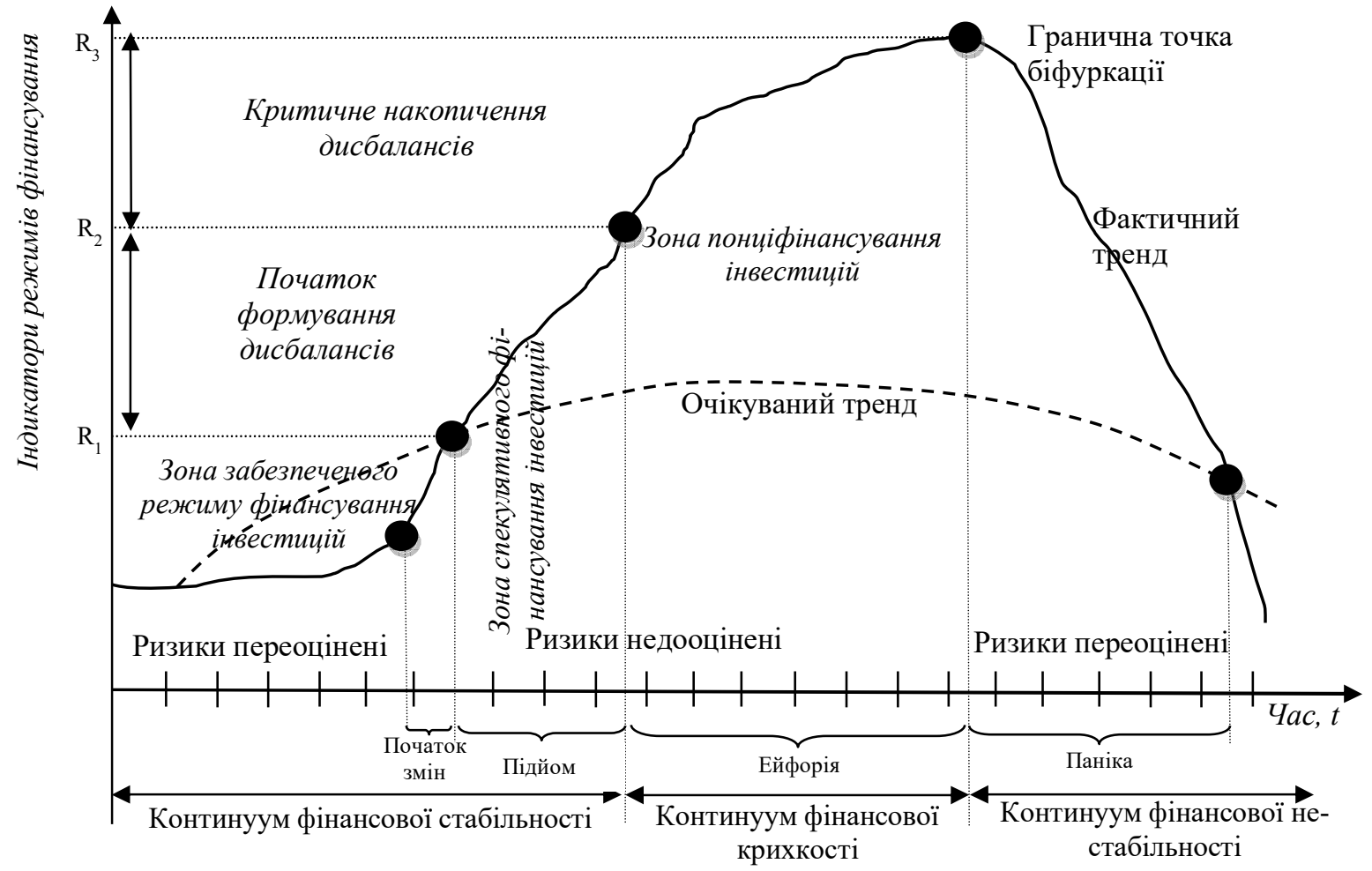

Рис. 1. Дескриптивна модель ичиклічного розвитку банківських установ у розрізі типів режимів фінансування за Х. Мінскі

Джерело: побудовано авторами на основі [7, с. 77-79].

Представлена на рис. 1 модель ілюструє межі функціонування фінансової стабільності банків, а також початок формування та критичного накопичення дисбалансів. Останні, на наш погляд, є основною причиною зниження фінансової стабільності банківських установ. 3 огляду на зазначене можна констатувати, що методологічним базисом обгрунтування змісту діагностичної компоненти фінансової стабільності має бути зворотний підхід для формування інструментів ідентифікації та оцінки дисбалансів, значущості їх впливу на рівень фінансової стабільності банків.

Звідси зрозуміло, що фінансову стабільність банків можна тлумачити через комплексне представлення структурних компонентів, які формують внутрішнє середовище для скоординованого функціонування іiї суб' єктів з метою розроблення та реалізації цілеспрямованих рішень щодо захисту іï об'єктів від внутрішніх та зовнішніх загроз фінансовій стабільності на основі вибору методів, важелів, інструментів їх виявлення, нейтралізації, мінімізації та протидії, ураховуючи як умови зовнішнього середовища (у тому числі, фази економічного циклу), так і вид та рівень системної важливості окремих кредитних установ. 
Політика банків у сфері забезпечення фінансової стабільності є сполучною ланкою між концепцією забезпечення фінансової стабільності банківських установ, яка являє собою науково обгрунтовану систему поглядів на процес попередження/ адаптації / протидії / мінімізації наслідків внутрішніх та зовнішніх загроз фінансовій стабільності банків у певній країні, та їхньою стратегією у сфері забезпечення фінансової стабільності (рис. 2).

\section{Мезорівень}

Мікрорівень

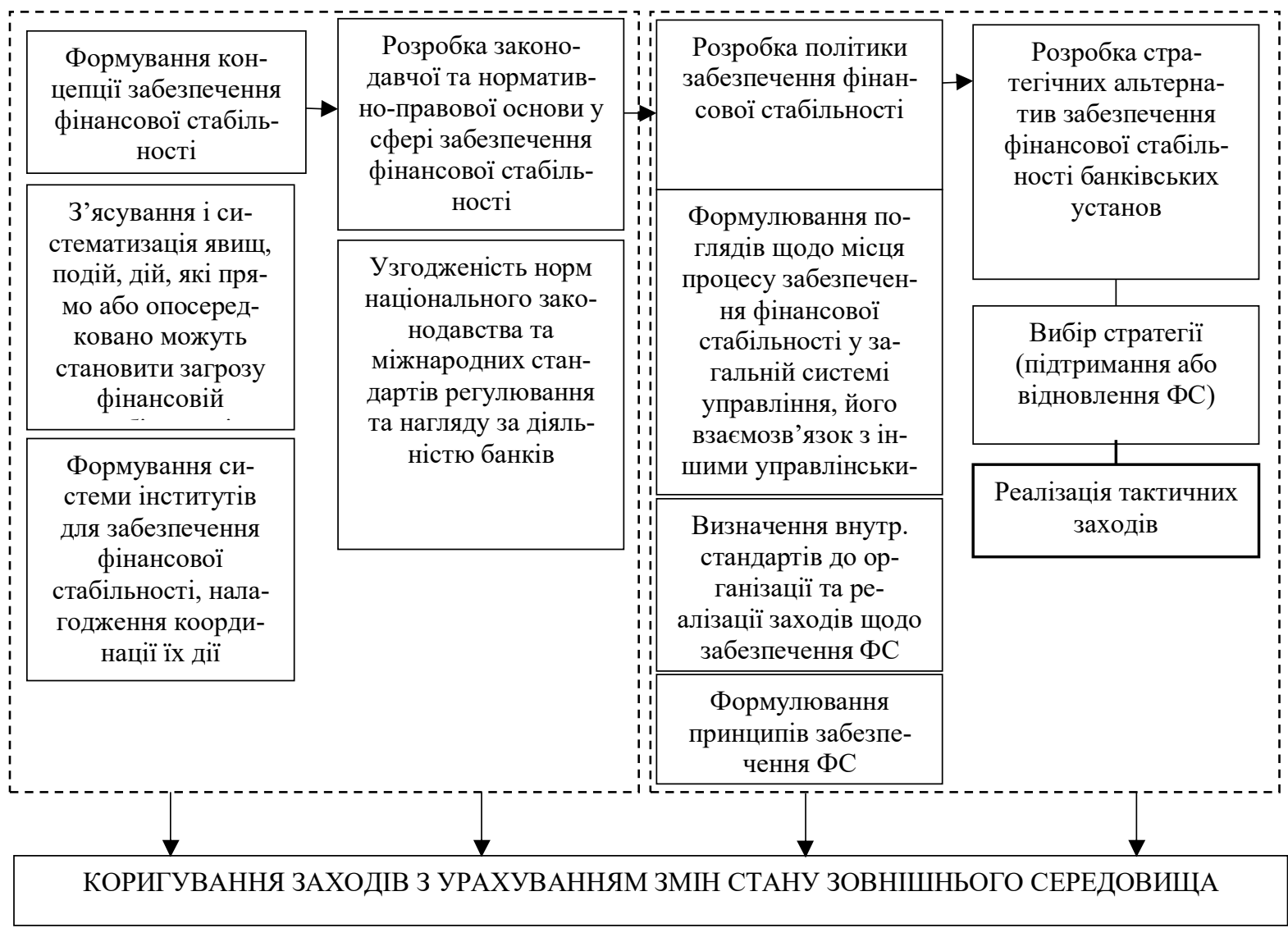

Рис. 2. Зміст базових заходів з формування системи забезпечення фінансової стабільності банків

* ФС - фінансова стабільність банків

Джерело: розроблено авторами.

На нашу думку, за умови незмінності цільового орієнтира діяльності банківських установ та збереження традиційної, орієнтованої на максимізацію ефективності використання капіталу бізнес-моделі, у нових умовах функціонування (посилення регуляторних вимог, нова парадигма регулювання, несприятливі економічні умови 3 погляду забезпечення високої рентабельності бізнесу) банки попадуть у стратегічну «пастку». Вона насамперед полягає в неможливості, орієнтуючись виключно на показник ROE, забезпечити зростання вартості бізнесу в довгостроковій перспективі (рис. 3). 
ФІНАНСОВІ РЕСУРСИ: ПРОБЛЕМИ ФОРМУВАННЯ ТА ВИКОРИСТАННЯ

\section{Зовнішній чинник}

Посилення регуляторних вимог, поточні несприятливі економічні умови, стійка тенденція до зниження відсоткових ставок

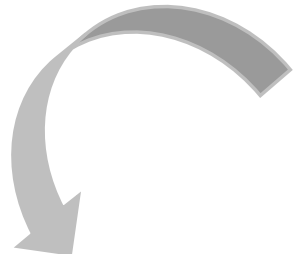

Зосередження банків на тих видах діяльності, які одночасно дозволяють мінімізувати витрати на виконання регуляторних норм та забезпечити прибутковість

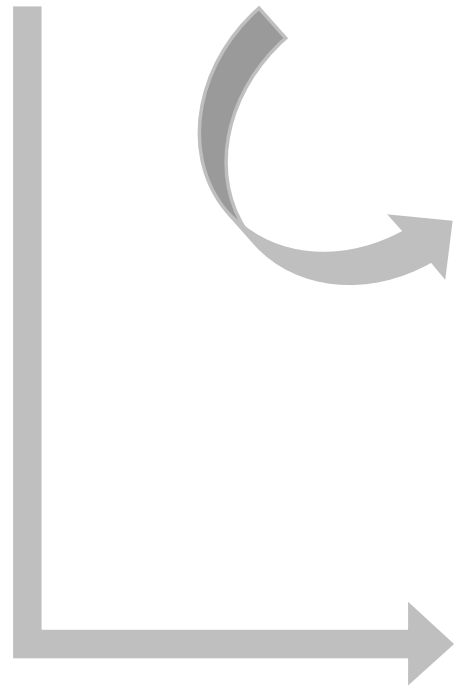

Зниження можливостей банківських установ до підвищення прибутковості за одночасного зростання потреб у капіталі

Використання традиційної бізнес-моделі (цільовий орієнтир - зростання вартості бізнесу на основі максимізації ROE) в умовах нових регуляторних вимог

\footnotetext{
Використання системного підходу до формування вартості бізнесу (розширений набір цільових орієнтирів)
}

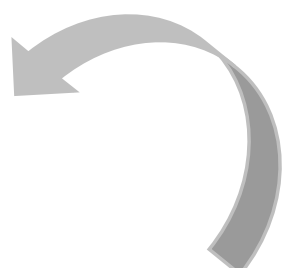

Орієнтація банків на тих напрямах вкладення коштів, які забезпечують швидке генерування прибутку (короткострокові, швидкоокупні, однак, зі слабким впливом на забезпечення сталого розвитку економіки)
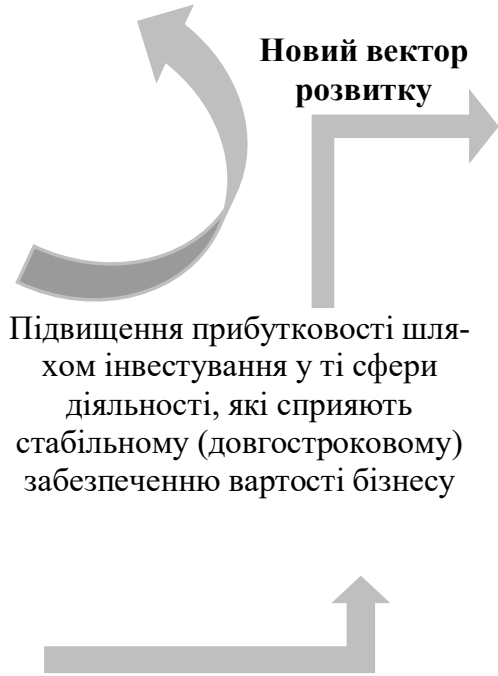

Рис. 3. Зміст стратегічної «пастки» банків за умови одновекторності їхніх иілььових орієнтирів

Джерело: розроблено авторами з урахуванням [8].

3 огляду на вищезазначене, видається доцільним говорити про імплементацію ідей концепції сталого розвитку в методологію забезпечення фінансової стабільності банківських установ. Варто зауважити, що рівень ііі імплементації в діяльність економічних агентів, особливо стосовно фінансових посередників, невпинно змінюється. Так, у звіті Європейської комісії 1997 року про роль фінансових установ у забезпеченні сталого розвитку увага акцентується на тому, що фінансові посередники, незважаючи на те, що не належать до «брудних» виробництв, не повинні стояти осторонь процесу забезпечення екостабільності людства [9].

Сучасна практика доводить, що в теорії та практиці банківництва особливої значущості набувають такі напрями управління банківською установою та забезпечення іiі фінансової стабільності - функціональний, ситуаційний та процесний. Так, функціональний напрямок пов'язаний із окремими елементами аналізу, регулювання та контролю в практиці банківської діяльності. У свою чергу, ситуаційний напрям активно поширився у практиці антикризового управління, управління ліквідністю та прибутковістю. Говорячи про процесний напрям у контексті забезпечення фінансової стабільності вар- 
то наголосити на систематичній ідентифікації та управлінні взаємопов'язаними процесами (під останніми варто розуміти будь-яку діяльність банківської установи, у процесі якої формуються продукти чи послуги в результаті перетворення вхідних потоків) [10].

Ключова перевага процесного напряму над функціональним полягає в безперервності управління фінансовою стабільністю, що забезпечується поєднанням окремих процесів у межах певної системи, а також при їх комбінуванні та взаємодії. Саме управління процесами сприяє швидкому адаптуванню діяльності банківської установи до трансформацій зовнішнього та внутрішнього середовищ, а й відповідно і покращенню якості своєї діяльності. До речі, побудова ефективної системи управління процесами передбачає високий рівень організації їх виконання, і це, у свою чергу, є базисом для обгрунтованого внутрішнього контролю та управління операційним ризиком.

На нашу думку, згідно з процесним підходом до управління фінансовою установою загалом, так і створення умов для забезпечення фінансової стабільності банків, можна виділити сукупність вимог (табл. 2).

Таблиця 2

Систематизачія вимог щуодо управління банком

у контексті забезпечення його фінансової стабільності

\begin{tabular}{|c|c|}
\hline $\begin{array}{c}\text { Найменування } \\
\text { окремої складової }\end{array}$ & Характеристика вимог до окремої складової процесу \\
\hline Продуктова & $\begin{array}{l}\text { Вимоги до якісних і кількісних продуктів , клієнтської бази та стратегічного роз- } \\
\text { витку банку загалом }\end{array}$ \\
\hline Технологічна & $\begin{array}{l}\text { Вимоги до технології продукування банківських продуктів/послуг, забезпечуваль- } \\
\text { них процесів та якості формалізованого їх опису тощо }\end{array}$ \\
\hline Організаційна & $\begin{array}{l}\text { Вимоги до організаційної структури, функціональному розподілу між окремими під- } \\
\text { розділами банківської установи, розмежування обов’язків і відповідальності тощо }\end{array}$ \\
\hline Управлінська & $\begin{array}{l}\text { Вимоги до формування управлінських документів, організації виконання функцій } \\
\text { менеджменту; процедурності, якості та ефективності внутрішнього контролю; управ- } \\
\text { ління внутрішніми та зовнішніми ризиками; організації прийняття рішень тощо }\end{array}$ \\
\hline Інформаційна & $\begin{array}{l}\text { Вимоги до складу, якості, джерел, способів обробки та зберігання інформації, ви- } \\
\text { моги до організації управління інформаційними потоками }\end{array}$ \\
\hline Кадрова & $\begin{array}{l}\text { Вимоги до працівників банківської установи, тобто закріплення функціональних } \\
\text { напрямків, вимоги до навчання і підвищення кваліфікації, встановлення системи } \\
\text { мотивації працівників }\end{array}$ \\
\hline Клієнтська & $\begin{array}{l}\text { Вимоги до забезпечення прозорості процесу для окремого клієнта та інших заці- } \\
\text { кавлених осіб }\end{array}$ \\
\hline Майнова & $\begin{array}{l}\text { Вимоги до кількісних і якісних характеристик використовуваного обладнання, } \\
\text { техніки, споруд, транспорту та ін. }\end{array}$ \\
\hline $\begin{array}{l}\text { Програмно- } \\
\text { технічна }\end{array}$ & $\begin{array}{l}\text { Вимоги до засобів обробки та зберігання інформації, тобто програмного забезпе- } \\
\text { чення та ін. }\end{array}$ \\
\hline
\end{tabular}

3 табл. 2 виходить, що фінансовій стабільності банку властиві функції генерування грошових потоків та забезпечення матеріальної основи функціонування фінансової установи, формування резервів як для покриття наслідків несприятливих подій, так і для досягнення активізації нових напрямів роботи, а також для забезпечення поступального фінансово стабільного розвитку за рахунок перерозподілу фінансових потоків.

Висновки та пропозиції. Зважаючи на вищезазначене, можна зробити висновок, що фінансова стабільність банку є широким комплексним поняттям, що включає в себе розгляд питань фінансово-економічного, організаційного та технічного порядку. Проблема забезпечення фінансової стабільності банківських установ вимагає розв'язання сукупності завдань: підвищення рівня капіталізації та активів банків, наявність довгострокових джерел фінансування банків, формування ефективної системи управління різними процесами в середині кожної банківської установи, формування сучасних підходів до управління ризиками та ін. Звідси зрозуміло, що функціональність побудованої системи управління фінансовою стабільністю окремого банку повинна доповнюватися такими функціями: 
ФІНАНСОВІ РЕСУРСИ: ПРОБЛЕМИ ФОРМУВАННЯ ТА ВИКОРИСТАННЯ

- діагностично-прогнозною (формування системи якісного оцінювання фінансової стабільності банківських установ шляхом збору та обробки інформації щодо умов зовнішнього середовища та діагностика його поточного / потенційного впливу на здатність установи безперервно виконувати свої основні функції, ураховуючи рівень внутрішніх дисбалансів; виявлення та оцінка загроз фінансовій стабільності банків, моделювання можливих наслідків їх реалізації);

- балансовою (забезпечення такого рівня збалансованості внутрішнього середовища кредитної установи / кредитного сегмента фінансового сектору, що дозволяє протистояти розвитку внутрішніх та впливу зовнішніх загроз фінансовій стабільності забезпечення такого рівня, яка дозволяє протистояти розвитку внутрішніх та впливу зовнішніх загроз фінансової стабільності);

- комунікаційною (налагодження якісного процесу обміну інформацією між суб'єктами забезпечення фінансової стабільності банків, тобто своєчасного, об'єктивного, повного);

- превентивною (провадження в практику діяльності превентивних заходів щодо подолання або мінімізації наслідків дії загроз, вибір інструментів та методів для попередження / протидії / мінімізації негативних наслідків їх накопичення та розвитку);

- гармонізаційною та захисною (досягнення балансу прав і обов'язків споживачів та надавачів фінансових послуг на ринку);

- просвітницькою (підвищення фінансової грамотності споживачів фінансових послуг банківських установ).

\section{Список використаних джерел}

1. Minsky H. P. Financial Stability Revisited: The Economics of Disaster. Board of Governors of the Federal Reserve System, Reappraisal of the Federal Reserve Discount Mechanism, Washington, D.C, 1972.87 p. URL: https://fraser.stlouisfed.org/files/docs/historical/federal\%20reserve\%20history/ discountmech/fininst_minsky.pdf.

2. Minsky H. P. The Financial Instability Hypothesis. The Jerome Levy Economics Institute of Bard College. 1992. Working Paper № 74. 10 p. URL: http://www.levyinstitute.org/pubs/wp74.pdf.

3. Crockett A. The Theory and Practice of the Financial Stability. Essay in International Finance. Princeton University. 1997. No 203. 52 p.

4. Ferguson R. Should Financial Stability Be An Explicit Central Bank Objective? Challenges to Central Banking from Globalized Financial Systems : IMF Conference (September 16-17, 2002). Washington, D.C., 2002. 13 p. URL: https://www.imf.org/external/pubs/ft/seminar/2002/gfs/eng/ ferguson.pdf.

5. Large A. Financial Stability: Maintaining Confidence in a Complex World. Speech at City of London Central Banking Conference (National Liberal Club, 17 November 2003). London: Bank of England. URL: http://www.bankofengland.co.uk/archive/Documents/historicpubs/speeches/2003/ speech205.pdf.

6. Schinasi G. Defining Financial Stability. IMF Working Paper. WP/04/187. 2004. 19 p. URL: https://pdfs.semanticscholar.org/ef31/bd3236697c658746235e96ab 920488ad5a3a.pdf.

7. Луняков О. В. Формирование, анализ и регулирование дисбалансов в финансовом секторе экономики Украины : дис. д-ра экон. наук : 08.00.08 / ГВУЗ «Украинская академия банковского дела Национального банка Украины». Сумы, 2013. 482 с.

8. Baranovskyi O., Khutorna M. Institutional Environment as a Precondition of an Effective System of Ensuring Credit Institutions' Financial Stability. Knowledge - Economy - Society. Contemporary Challenges of Economic Resources Management. Book III. Cracow University of Economics, 2018. Pp. 33-44.

9. Delphi International LTD in Association with Ecologic GMBH. The Role of Financial Institutions in Achieving Sustainable Development. Report to the European Comission, 1997. URL: http://ec.europa.eu/environment/archives/ finserv/fisum.pdf. 
10. Ткаченко Н. В., Рожко О. Д., Момот О. М. Наукові засади управління ризиками транснаціональних банків. Збірник наукових праџь «Фінансово-кредитна діяльність: проблеми теорії та практики». 2019. Т 1, № 28. С. 55-63.

\section{References}

1. Minsky, H. P. (1972). Financial Stability Revisited: The Economics of Disaster. Board of Governors of the Federal Reserve System, Reappraisal of the Federal Reserve Discount Mechanism, Washington, D.C. https://fraser.stlouisfed.org/files/docs/historical/federal\%20reserve\%20history/ discountmech/fininst_minsky.pdf.

2. Minsky, H.P. (1992). The Financial Instability Hypothesis. The Jerome Levy Economics Institute of Bard College. Working Paper, (74). http://www.levyinstitute.org/pubs/wp74.pdf.

3. Crockett, A. (1997). The Theory and Practice of the Financial Stability. Essay in International Finance. Princeton University, (203).

4. Ferguson, R. (2002). Should Financial Stability Be An Explicit Central Bank Objective? Challenges to Central Banking from Globalized Financial Systems : IMF Conference (September 1617, 2002). D.C. https://www.imf.org/external/pubs/ft/seminar/2002/gfs/eng/ferguson.pdf.

5. Large, A. (2003). Financial Stability: Maintaining Confidence in a Complex World. Speech at City of London Central Banking Conference (National Liberal Club, 17 November 2003). Bank of England. http://www.bankofengland.co.uk/archive/Documents/historicpubs/speeches/2003/speech205.pdf.

6. Schinasi, G. (2004). Defining Financial Stability. IMF Working Paper. WP/04/187. https://pdfs.semanticscholar.org/ef31/bd3236697c658746235e96ab 920488ad5a3a.pdf.

7. Lunyakov, O. V. (2013). Formirovaniye, analiz i regulirovaniye disbalansov $v$ finansovom sektore ekonomiki Ukrainy [Formation, analysis and regulation of imbalances in the financial sector of the Ukrainian economy] [Doctor's dissertation; Ukrainskaia akademiia bankovskogo dela Natsionalnogo banka Ukrainy].

8. Baranovskyi, O., \& Khutorna, M. (2018). Institutional Environment as a Precondition of an Effective System of Ensuring Credit Institutions' Financial Stability. Knowledge - Economy - Society. Contemporary Challenges of Economic Resources Management. Book III. Cracow University of Economics.

9. Delphi International LTD in Association with Ecologic GMBH. (1997). The Role of Financial Institutions in Achieving Sustainable Development. Report to the European Comission. http://ec.europa.eu/environment/archives/finserv/fisum.pdf.

10. Tkachenko, N. V., Rozhko, O. D., \& Momot, O. M. (2019). Naukovi zasady upravlinnia ryzykamy transnatsionalnykh bankiv [Scientific principles of risk management of transnational banks]. Zbirnyk naukovykh prats «Finansovo-kredytna diyal'nist: problemy teoriyi ta praktyky»Collection of scientific works «Financial and credit activities: problems of theory and practice», 1(28), pp. 55-63.

Ткаченко Наталія Володимирівна - доктор економічних наук, професор, Інститут післядипломної освіти Київського національного університету імені Тараса Шевченка (вул. Васильківська, 36, м. Київ, 03022, Україна).

Ткаченко Наталья Владимировна - доктор экономических наук, профессор, Институт последипломного образования Киевского национального университета имени Тараса Шевченко (ул. Васильковская, 36, г. Киев, 03022, Украина).

Tkachenko Nataliia - Doctor of Economics, Professor, Institute of Postgraduate Education of Taras Shevchenko Kyiv National University (36 Vasylkivska Str., 03022 Kyiv, Ukraine).

E-mail: tkachenkonnt@ukr.net

ORCID ID: 0000-0001-6312-4586

Хуторна Мирослава Емілівна - доктор економічних наук, доцент, професор кафедри фінансів та банківської справи Черкаського навчально-наукового інституту Університету банківської справи (вул. В. Чорновола, 164, м. Черкаси, 18029, Україна).

Хуторна Мирослава Эмильевна - доктор экономических наук, доцент, профессор кафедры финансов и банковского дела Черкасского учебно-научного института Университета банковского дела (ул. В. Черновола, 164, г. Черкассы, 18029, Украина).

Khutorna Myroslava - Doctor of Economics, Associate Professor, Professor of the Department of Finance and Banking of the Cherkasy Educational and Scientific Institute of Banking University (164 V. Chornovola Str., 18029 Cherkasy, Ukraine).

E-mail: lmiroslava7@gmail.com

ORCID ID: 0000-0003-0761-3021

Ткаченко Н., Хуторна М. Наукові підходи до забезпечення фінансової стабільності банків 3 позиції сучасної трансформації економічного середовища. Проблеми і перспективи економіки та управління. 2020. № 4(24). С. 112-120. 